\title{
NUTRITIONAL BUDGETS IN FREE FLYING BIRDS: CEDAR WAXWINGS (BOMBYCILLA CEDRORUM) FEEDING ON WASHINGTON HAWTHORN FRUIT (CRATAEGUS PHAENOPYRUM)
}

\author{
Eugene H. Studier, Ernest J. Szuch, Terence M. Tompkins and Virgil W. Cope* \\ Department of Biology, The University of Michigan-Flint, Flint, MI 48502-2186, USA.
}

(Received 12 June 1987)

\begin{abstract}
Nutritional balances for calories, glucose, water, nitrogen, $\mathrm{Na}^{+}, \mathrm{K}^{+}, \mathrm{Ca}^{2+}$, and $\mathrm{Mg}^{2+}$ have been estimated for free-flying cedar waxwings feeding on Washington hawthorn fruits.

2. Birds assimilate 39.9 calories/fruit $(=20.0 \%$ of available calories) and a net loss of $155 \mathrm{mg}$ of water/fruit.

3. Reducing sugars account for $74.5 \%$ of assimilated calories $(=66.0 \%$ assimilation efficiency).

4. While feeding on these fruits, birds exhibit positive nitrogen and caloric balance, and negative $\mathrm{Na}^{+}$, $\mathrm{K}^{+}, \mathrm{Mg}^{2+}, \mathrm{Ca}^{2+}$, and water balances.
\end{abstract}

\section{INTRODUCTION}

Estimates of nutritional (caloric, water, nitrogen, mineral, etc.) budgets in birds and other animals routinely utilize subjects fed on a single item or otherwise defined diet. Analysis of ingestion rates and levels or concentrations of those nutrients allows calculation of input for the components measured. Output or loss of nutrients requires measurement of levels of nutrients in and amount of wastes produced from ingestion of the dietary item. The difference between input (gain) and output (loss) estimates relative assimilation of the nutrients measured. In view of these requirements, published studies of nutritional budgets have been routinely done with caged animals (Walsberg, 1975; Sugden et al., 1981; Johnson et al., 1985). Components of nutritional economics in small, feral mammals are markedly affected by captivity (Bakko, 1977; Studier and Wilson, 1979) and caging may similarly be expected to affect bird nutrition. Data collected on caged animals certainly reflect a physiological capability of the organism but may give biased estimates of natural function in free individuals. While labelled water techniques have been used to study some aspects of nutritional budgets in free-flying birds, those studies require repeated capture of studied individuals, are invasive, and have high errors of estimates (Weathers and Nagy, 1980).

Our study describes a method for determination of nutritional budgets of completely free cedar waxwings (Bombycilla cedrorum) feeding naturally on the fruits of Washington hawthorn (Crataegus phaenopyrum), Early each spring (February or March), one or more flocks of cedar waxwings feed intensively for a period of several weeks on the fruits of five hawthorn trees located along the south side of our laboratory building. Birds appear to feed exclusively on the hawthorn pomes for most of the daylight hours each day. Birds exhibit a very rapid passage

*Department of Chemistry, The University of MichiganFlint, Flint, MI 48502-2186, USA. time with elimination of ingested pomes beginning in less that $20 \mathrm{~min}$, although feeding bouts frequently last longer than $1 \mathrm{hr}$. Mixed wastes, therefore, accumulate rapidly beneath the trees while feeding continues. Each hawthorn fruit invariably $(n>100)$ contains five seeds which are not crushed or digested in passage through the bird's gut. Such lack of seed digestion has been reported for waxwings ingesting other fruits (Pulliainen and Erkinaro, 1978). Waxwings do not regurgitate hawthorn fruits or seeds as many frugivorous birds do (Johnson et al., 1985). This technique would, however, also be applicable to birds which do regurgitate fruits or fruit parts. By determining average number of seeds per fruit and counting the seeds present in waste samples, it is, therefore, possible to determine the original number of whole pomes represented by any sample of mixed wastes and avoids the limitations of other methods (Herrera, 1984; Herrera and Jordano, 1981). The analysis of subsamples of a large original sample of mixed wastes produced by many waxwings over a 1-2 hr period insures homogeneous distribution of the natural marker in digesta and excreta. The existence of a natural marker in both food and wastes coupled to component analysis allows calculation of nutritional economics on a per fruit or per seed basis.

\section{MATERIALS AND METHODS}

Fruit and waste samples were collected the first week of March 1981. Hawthorn fruits were gathered from branches clipped from the trees in which the waxwings were, or had recently been, feeding. Pomes just about to abscise were selected for analysis. Mixed wastes were collected between sunrise and $10 \mathrm{a} . \mathrm{m}$. from plastic sheets that were spread under roost (feeding) trees just prior to or during feeding bouts. Fruits and wastes were weighed $(0.1 \mathrm{mg})$ immediately after collection.

Some fruit and waste samples, after weighing, were placed on ice to inhibit hydrolysis. These samples (including seeds) were then ground, while being kept chilled, with a Brinkman Kinematica PCU1, filtered, and tested for reducing sugars (primarily glucose), using the Nelson test as described by Clark (1964). Remaining fruit and waste samples were dried 
to constant weight in an oven at $55-60^{\circ} \mathrm{C}$ to determine water content. Number of seeds in waste samples was counted to determine the number of original fruits represented in the waste samples. For both fruits and wastes, pulp was then separated from the seeds by hand. Pulp dry weight and seed dry weight for both fruits and wastes were then determined.

Caloric content of the pulp fraction of both fruits and wastes was measured by pelleting those dry samples with primary standard benzoic acid and burning the pellets in a Parr oxygen bomb calorimeter (Model 1300). Samples (about $50 \mathrm{mg}$ each) of fruit and waste pulp were wet oxidized in $100 \mathrm{ml}$ volumetric flasks using $1 \mathrm{ml}$ of boiling concentrated $\mathrm{H}_{2} \mathrm{SO}_{4}$ containing several non-selenized Hengar granules, followed by addition of $3 \mathrm{ml}$ of $30 \%$ $\mathrm{H}_{2} \mathrm{O}_{2}$ : concentrated $\mathrm{H}_{2} \mathrm{SO}_{4}(2: 1 \mathrm{v} / \mathrm{v})$. After digestion was complete, samples were cooled and diluted to $100 \mathrm{ml}$. Onehalf $\mathrm{ml}$ aliquots were analyzed for nitrogen content by Nesslerization (Treybig and Haney, 1983).

Additional aliquots, after appropriate dilution and preparation, were analyzed for $\mathrm{Na}^{+}, \mathrm{K}^{+}, \mathrm{Ca}^{2+}$, and $\mathrm{Mg}^{2+}$ concentration following standard procedures using a Varian Spectra AA-20 atomic absorption spectrophotometer. (Analytical methods for flame spectroscopy, Varian Techtron Ptg. Ltd., Springvale, Australia).

Periodically, individual birds feeding on hawthorn pomes were observed between sunrise and $9 \mathrm{a} . \mathrm{m}$. and direct counts of fruits eaten/time and passage time were determined. Samples and data were collected just after dawn to ensure that all measurements reflect only ingestion and processing of hawthorn fruits.

\section{RESULTS}

Data on fresh and dry composition, as well as glucose concentrations and caloric density of ingested hawthorn pomes and resultant mixed wastes, are given in Table 1 . Water content of mixed wastes is much higher than in ingested fruits resulting in a net loss of $155 \mathrm{mg} /$ fruit $(0.182-0.027 \mathrm{mg} /$ fruit, Table 1$)$. In fruits, $44.3 \%(0.796 / 1.796 \times 100$, Table 1$)$ of dry mass was pulp, while for mixed wastes, $39.0 \%$ $(0.639 / 1.639 \times 100$, Table 1$)$ of dry mass was pulp. Ingested pulp/fruit, therefore, was $47.0 \mathrm{mg}(=0.443$ $\times 106 \mathrm{mg} /$ fruit, Table 1) while waste pulp/fruit was

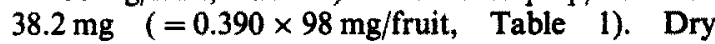
assimilation efficiency then is $18.7 \%(=8.8 / 47.0 \times$ 100). Ingested pulp energy is $199.6 \mathrm{cal} / \mathrm{fruit}$ $(=0.047 \mathrm{~g} /$ fruit $\times 4250 \mathrm{cal} / \mathrm{g}$ ) while egested energy is $159.7 \mathrm{cal} / \mathrm{fruit} \quad(=0.0382 \mathrm{~g} / \mathrm{fruit} \times 4180 \mathrm{cal} / \mathrm{g})$ yielding caloric assimilation of $39.9 \mathrm{cal} / \mathrm{fruit}$ or $20.0 \%$ of ingested calories. Glucose intake was $10.72 \mathrm{mg} / \mathrm{fruit}$ $(=80.6 \mathrm{mg} / \mathrm{g}$ fresh weight $\times 0.133 \mathrm{~g}$ fresh weight/ fruit, Table 1) with losses of $3.64 \mathrm{mg} /$ fruit $(13.0 \mathrm{mg} / \mathrm{g}$ fresh weight $\times 0.280 \mathrm{~g}$ fresh weight/fruit) yielding a
Table 1. Measured and calculated nutritional parameters of fruits and mixed wastes of cedar waxwings feeding on hawthorn pomes. Values are means \pm standard error of the means. Sample sizes are shown in parentheses. Entries marked with an asterisk (") represent average values per 5 seeds in mixed wastes from 70 original pomes (= 350 seeds). See text for further explanation

\begin{tabular}{lcc}
\hline Parameter & Fruit & Wastes \\
\hline Fresh weight (g/fruit) & $0.133 \pm 0.006$ & $0.280^{*}$ \\
Dry weight (g/fruit) & $(20)$ & \\
& $0.106 \pm 0.004$ & $0.098^{*}$ \\
Water (g/fruit) & $(20)$ & \\
& $0.027 \pm 0.002$ & $0.182^{*}$ \\
Water (\%) & $(20)$ & \\
& $20.0 \pm 0.5$ & $65.0^{*}$ \\
Dry pulp (g/g dry seeds) & $(20)$ & \\
Total fresh weight (g/g dry seeds) & 0.796 & 0.639 \\
Glucose (mg/g fresh weight) & 2.25 & 4.79 \\
& $(29)$ & $13.0 \pm 2.0$ \\
Glucose (mg/g dry seeds) & 182.0 & $(20)$ \\
Pulp energy (cal/g dry weight) & $4250.0 \pm 53.0$ & $4180.0 \pm 38.0$ \\
& $(10)$ & $(10)$ \\
Water (g/g dry seeds) & 0.456 & 3.11 \\
\hline
\end{tabular}

net gain of $7.08 \mathrm{mg} /$ fruit and an assimilation efficiency of $66.0 \%$. The caloric density of glucose is $4.2 \mathrm{cal} / \mathrm{mg}$ (Kleiber, 1961); therefore, assimilation of glucose represents $29.74 \mathrm{cal} / \mathrm{fruit}$ or $74.5 \%$ of assimilated cal/fruit.

Values for nitrogen and mineral levels in the dry pulp of fruits and wastes as well as values/fruit are given in Table 2. Dry pulp concentration $(\mathrm{mg} \%$ ) of each mineral tested is significantly greater in wastes than in fruits $\left(\mathrm{Na}^{+}: \mathrm{t}=3.28,14 \mathrm{df}, P<0.01 ; \mathrm{K}^{+}\right.$: $t=6.07,14 \mathrm{df}, P<0.001 ; \mathrm{Ca}^{2+}: t=13.2,14 \mathrm{df}$, $\left.P<0.001 ; \mathrm{Mg}^{2+}: t=22.4,14 \mathrm{df}, P<0.001\right)$. Based on the in/out differential and in/out ratio, while consuming hawthorn fruits, cedar waxwings are in slightly positive nitrogen balance, are nearly in $\mathrm{K}^{+}$ balance, and are in marked negative balances for $\mathrm{Mg}^{2+}, \mathrm{Ca}^{2+}$, and $\mathrm{Na}^{+}$.

Feeding frequency during early morning hours was counted for 33 individual birds on separate occasions for time spans averaging 30 sec. Rate of fruit eating was $14.5 \pm 2.9$ berries/min (range $=$ 2.5-28.6). Based on observations made at dawn, time between first morning feeding and waste elimination was $14-16 \mathrm{~min}$ and corresponds to observations made by Nice (1941).

\section{DISCUSSION}

The fruits of various species of Crataegus are described as fall ripe, low quality (Stiles, 1980). Such

Table 2. Levels of nitrogen and selected minerals in fruit eaten and wastes produced by cedar waxwings feeding on hawthorn pomes. Values shown are means \pm (standard errors of the means). Sample size is 8 in each case

\begin{tabular}{|c|c|c|c|c|c|c|}
\hline \multirow[b]{2}{*}{ Sample } & \multirow{2}{*}{$\begin{array}{c}\mathrm{mg} \\
\mathrm{dry} w t\end{array}$} & \multicolumn{5}{|c|}{$\mathrm{mg} / 100 \mathrm{mg}$ dry weight } \\
\hline & & $\mathbf{N}$ & $\mathrm{Na}^{+}$ & $\mathbf{K}^{+}$ & $\mathrm{Ca}^{2+}$ & $\mathrm{Mg}^{2+}$ \\
\hline In = fruit & $\begin{array}{l}56.6 \\
677\end{array}$ & 1.47 & 0.19 & 2.22 & $\begin{array}{c}0.60 \\
(0.02)\end{array}$ & $\begin{array}{c}0.181 \\
(0.004)\end{array}$ \\
\hline Out $=$ wastes & $\begin{array}{l}58.2 \\
(0.9)\end{array}$ & $\begin{array}{c}1.57 \\
(0.05)\end{array}$ & $\begin{array}{c}0.44 \\
(0.07)\end{array}$ & $\begin{array}{c}2.78 \\
(0.09)\end{array}$ & $\begin{array}{c}1.19 \\
(0.04)\end{array}$ & $\begin{array}{c}0.313 \\
(0.005)\end{array}$ \\
\hline $\begin{array}{l}\text { In } \\
\text { Out } \\
\text { Difference } \\
\text { In/out }\end{array}$ & & $\begin{array}{r}0.691 \\
0.600 \\
+0.091 \\
1.15\end{array}$ & $\begin{array}{r}0.0893 \\
0.1681 \\
-0.0788 \\
0.531\end{array}$ & $\begin{array}{c}\mathrm{mg} / \mathrm{fruit} \\
1.04 \\
1.06 \\
-0.02 \\
0.981\end{array}$ & $\begin{array}{r}0.282 \\
0.455 \\
-0.173 \\
0.620\end{array}$ & $\begin{array}{r}0.0851 \\
0.1196 \\
-0.0345 \\
0.712\end{array}$ \\
\hline
\end{tabular}


fruits are low in lipids and sugars and are retained on the plant well into the winter. As in other fruits, ripening is apparently associated with the activation of intrinsic amylases (Whiting, 1970) which catalyse the hydrolysis of starch into monosaccharides and disaccharides. As ripening progresses, microbes begin to ferment the simpler sugars to produce ethanol. The timing of arrival and feeding by cedar waxwings during their gradual northward spring movement allows them to ingest ripened, but not highly alcoholic fruits (Janzen, 1977). Ingestion of prehydrolysed starch from fruit pulp may also conserve the energy required for amylase synthesis and would speed assimilation during the very rapid passage time. The very low water content of hawthorn fruits may be a ripening strategy which prevents premature fermentation of pulp carbohydrates.

Fruits consumed by birds vary widely in composition (Johnson et al., 1985; Sorensen, 1981). With the exception of water content and Sorensen's caloric data, composition of hawthorn fruits falls well within published ranges. Dry mass assimilation efficiency $(18.7 \%)$ and caloric assimilation efficiency $(20.0 \%)$ by cedar waxwings feeding on hawthorn fruits are much lower than values reported for other frugivorous birds (Walsberg, 1975; Johnson et al., 1985). These other studies, however, were performed with caged birds. No studies comparing assimilation efficiencies of one species under both free living and caged conditions are available. We postulate that the assimilation efficiencies reported for caged birds, while within functional capacity, would be markedly higher, perhaps due to caging stress, than assimilation efficiency of free living birds.

Not surprisingly, glucose assimilation efficiency, $66.0 \%$, is very much higher than general caloric assimilation efficiency. Similarly, glucose uptake represents $74.5 \%$ of assimilated calories which points out the extreme value of appropriate timing of ingestion of hawthorn fruits after ripening but before fermentation.

According to Dunning (1984), adult female cedar waxwings weigh $33.1 \pm 1.07 \mathrm{~g}(n=190)$ and males weigh $30.6 \pm 1.72 \mathrm{~g}(n=58)$, Using an average weight for these birds of $32.0 \mathrm{~g}$, the equation for daily energy requirement (DER) presented for passerine birds by Lasiewski and Dawson (1967) predicts a requirement of $10.7 \mathrm{kcal} / \mathrm{day}$. Using a $12 \mathrm{hr}$ active: $12 \mathrm{hr}$ resting cycle for these birds in March, Aschoff and Pohl's (1970) equations estimate a DER of $11.0 \mathrm{kcal} /$ day for cedar waxwings. Assuming a DER of $10.8 \mathrm{kcal} / \mathrm{day}$, caloric demands would be satisfied by ingestion of 271 hawthorn fruits ( $=22.6$ fruits $/ \mathrm{hr}$ over a $12 \mathrm{hr}$ feeding span/day). It must be strongly emphasized that this estimate of DER is a theoretical minimum; and, although subsequent calculations are based on this minimum, actual DER for these waxwings is probably $2-3$ times higher than $10.8 \mathrm{Kcal} /$ day.

The much greater water content of mixed wastes compared to fruits $(155 \mathrm{mg} /$ fruit) indicates that body water is transferred into digesta and excreta during fruit passage which necessarily results in dehydration of the birds. Loss of additional unaccounted respiratory water would further exacerbate overall negative water balance. Water gain is thought to be one of the "rewards" for fruit foraging birds in some places/times (Willson, personal communication); however, the hawthorn fruits have much lower water levels than many other fruits consumed by birds (Johnson et al., 1985). Total body water in cedar waxwings ( $66 \%$ of live weight; Sturges et al., 1974) is $21.0 \mathrm{~g}$. Ingestion of sufficient hawthorn fruits to satisfy minimal caloric needs would, therefore, result in a daily minimal water loss of $42.0 \mathrm{~g}$ or twice the total body water of the birds. Actual daily water loss, as indicated above, is probably much greater than $42.0 \mathrm{~g}$. The dehydrating affect of hawthorn fruit ingestion explains our observations that these birds make frequent trips to drink at a temporary pond located within $200 \mathrm{~m}$ of the feeding trees. Drinking water obviously must be readily available whenever cedar waxwings feed on hawthorn fruits.

Cedar waxwings are in positive nitrogen balance while feeding on hawthorn pomes with a net average gain of $0.091 \mathrm{mg} /$ fruit. Robbins' (1981) equation $\left(0.07 \mathrm{~g} / \mathrm{kg}^{0.75} /\right.$ day) estimates a minimal daily nitrogen requirement of $5.28 \mathrm{mg} /$ day for $32.0 \mathrm{~g}$ passerines. Ingestion of the 271 fruits required to meet minimum daily caloric demands yields a daily nitrogen input of $187 \mathrm{mg}$ and a net gain of $24.6 \mathrm{mg}$ which certainly appears to meet minimal daily nitrogen needs. Total nitrogen content in cedar waxwings should be about $340 \mathrm{mg}$ (Sturges et al., 1974); therefore, total nitrogen consumed in meeting daily caloric needs represents about half of total body nitrogen and net positive gain represents about $7 \%$ of total body nitrogen.

Regarding mineral nutrition, cedar waxwings feeding on hawthorn fruits are nearly in $\mathrm{K}^{+}$balance, but are in definite negative balances for $\mathrm{Na}^{+}, \mathrm{Ca}^{2+}$, and $\mathrm{Mg}^{2+}$. Total body levels, estimated from Sturges $e t$ al. $(1974)$, are $\mathrm{Na}^{+}=44.6 \mathrm{mg}, \mathrm{K}^{+}=88.8 \mathrm{mg}, \mathrm{Ca}^{2+}=$ $340.0 \mathrm{mg}$, and $\mathrm{Mg}^{2+}=12.6 \mathrm{mg}$. Again assuming birds consume 271 fruits to meet minimal caloric needs, daily $\mathrm{K}^{+}$loss is $5.4 \mathrm{mg}(=6.1 \%$ of total body $\left.\mathrm{K}^{+}\right), \mathrm{Na}^{+}$loss is $21.4 \mathrm{mg}(=47.9 \%$ of total body $\mathrm{Na}^{+}$), $\mathrm{Ca}^{2+}$ loss is $46.9 \mathrm{mg}$ ( $=13.8 \%$ of total body $\mathrm{Ca}^{2+}$ ), and $\mathrm{Mg}^{2+}$ loss is $9.35 \mathrm{mg}(=74.2 \%$ of total body $\mathrm{Mg}^{2+}$ ). Each of these losses would be higher, of course, if birds consume more than the minimal number of fruits required to meet caloric demands. The greatest relative negative mineral balances are for $\mathrm{Mg}^{2+}$ and $\mathrm{Na}^{+}$. While we have not found comparable data for wild birds, Fisher (1972) suggests similar mineral requirements for domesticated birds and mammals. Literature on mineral nutrition in mammals indicates sodium stress occurs in many herbivores (see Aumann and Emlen, 1965; Botkin et al., 1973; Weeks and Kirkpatrick, 1978).

At a feeding rate of 14.5 berries/min, birds would consume 271 berries, and, therefore, meet estimated daily caloric demand in $18.7 \mathrm{~min}$ of feeding/day. Although individual birds rarely have been observed to feed continuously for over $1 \mathrm{~min}$, birds could very easily consume 271 berries during the $12 \mathrm{hr}$ of daylight and could easily consume twice that number.

From the previous discussion, it is apparent that hawthorn fruits do not provide complete nutritional needs for cedar waxwings. Hawthorn fruits appear to be eaten primarily as a readily available caloric and nitrogen source at a cost of extremely negative bud- 
gets for water and some common minerals. Ingestion of progressively more fruits places cedar waxwings in progressively more positive energy and nitrogen balance while simultaneously placing the birds in progressively greater water and mineral deficits.

Acknowledgements - We thank Drs James R. King, Thomas L. Poulson, John N. Thompson, and Mary F. Willson for their very useful comments on this manuscript. We thank Dr Jane Taylor for identification of the hawthorn. We also express our long overdue thanks and appreciation to our outgoing departmental secretary, Leila Taylor, for her aid in preparation of this and many previous manuscripts.

\section{REFERENCES}

Aschoff J. and Pohl H. (1970) Der Ruheumsatz von Vogeln als Funktion der Tageszeit und der Korpergrosse. $J$. Ornith. 111, 38-47.

Aumann G. D. and Emlen J. T. (1965) Relation of population density to sodium availability and sodium selection by microtine rodents. Nature 208, 198-199.

Bakko E. B. (1977) Influence of collecting techniques on estimates of natural renal function in red squirrels. $\mathrm{Am}$. Midland Nat. 97, 502-504.

Botkin D. P., Jordan P. A., Dominski A. S., Iowendorf H. S and Hutchinson G. E. (1973) Sodium dynamics in a northern ecosystem. Proc. natn. Acad. Sci. 70, 2745-2748.

Clark J. M. Jr (1964) Experimental Biochemistry. W. H. Freeman, San Francisco.

Dunning J. B. Jr. (1984) Body weights of 686 species of North American birds. Western Bird Banding Assoc., 38 pp. Eldon Publishers, Cave Creek, Arizona.

Fisher H. (1972) The nutrition of birds. In Avian Biology (Edited by Farner D. S. and King J. R.), Vol. 2, pp. 431-469. Academic Press, New York.

Herrera C. M. (1984) A study of avian frugivores, birddispersed plants, and their interaction in Mediterranean scrublands. Ecol. Monogr. 54, 1-23.

Herrera, C. M. and Jordano, P. (1981) Prunus mahaleb and birds: the high-efficiency seed dispersal system of a temperate fruiting tree. Ecol. Monogr. 51, 203-218.

Janzen D. H. (1977) Why fruits rot, seeds mold, and meat spoils. Am. Nat. 111, 691-713.

Johnson R. A., Willson M. F., Thompson J. N. and Bertin
R. I. (1985) Nutritional values of wild fruits and consumption by migrant frugivorous birds. Ecology 66, 819-827.

Kleiber M. (1961) The Fire of Life. Wiley, New York.

Lasiewski R. C. and Dawson W. R. (1967) A reexamination of the relation between standard metabolic rate and body weight in birds. The Condor 69, 13-23.

Nice N. M. (1941) Observations on the behavior of a young cedar waxwing. The Condor 43, 58-64.

Puliainen E. and Erkinaro E. (1978) The digestibility of rowan-berry seeds, Sorbus aucuparia L., for the waxwing, Bombycilla garrulus $\mathrm{L}$. as studied by scanning electron microscopy. Aquilo Ser. Zool. 18, 15-16.

Robbins C. T. (1981) Estimation of the relative protein cost of reproduction in birds. The Condor 83, 177-179.

Sorensen A. E. (1981) Interactions between birds and fruit in a temperate woodland. Oecologia. 50, 242-249.

Stiles E. W. (1980) Patterns of fruit presentation and seed dispersal in bird-disseminated woody plants in the Eastern deciduous forest. AM. Nat. 116, 670-688.

Studier E. H. and Wilson D. E. (1979) Effects of captivity on thermoregulation and metabolism in Artibeus jamaicensis (Chiroptera: Phyllostomatidae). Comp. Biochem. Physiol. 62A, 347-350.

Sturges F. W., Holmes R. T. and Likens G. E. (1974) The role of birds in nutrient cycling in a northern hardwoods ecosystem. Ecology 55, 149-155.

Sugden L. G., Driver E. A. and Kingsley M. C. S. (1981) Growth and energy consumption by captive mallards. Can. J. Zool. 59, 1567-1570.

Treybig D. S. and Haney P. L. (1983) Colorimetric determination of total nitrogen in amines with selenium catalyst. Anal. Chem. 55, 983-985.

Walsberg G. E. (1975) Digestive adaptations of Phainopepla nitens associated with the eating of mistletoe berries. The Condor. 77, 169-174.

Weathers W. W. and Nagy K. A. (1980) Simultaneous doubly labeled water $\left({ }^{3} \mathrm{HH}^{18} \mathrm{O}\right)$ and time-budget estimates of daily energy expenditure in Phainopepla nitens. The Auk. 97, 861-867.

Weeks H. P. Jr and Kirkpatrick C. M. (1978) Salt preferences and sodium drive phenology in fox squirrels and woodchucks. J. Mamm. 59, 531-542.

Whiting G. C. (1970) Sugars. In The Biochemistry of Fruits and Their Products (Edited by Hulme A. C.), Vol. 1, pp. 1-31. Academic Press, London. 